\title{
A Qualitative Enquiry into Professional Project Management Practices in the Ghanaian Construction Industry
}

\author{
E. Kissi ${ }^{1}$, D. K. Ahadzie $^{2}$ \& J. F. Cobbinah ${ }^{3}$ \\ ${ }^{1}$ Department of Building Technology, Kwame University of Science and Technology, Kumasi, Ghana \\ ${ }^{2}$ Centre for Settlement Studies, Kwame Nkrumah University of Science and Technology, Kumasi, Ghana \\ ${ }^{3}$ Department of Building Technology, Takoradi Polytechnic, Takoradi, Ghana \\ Corresponding: E. Kissi, Department of Building Technology, Kwame University of Science and Technology, \\ Kumasi, Ghana. E-mail: kisernest@yahoo.com
}

Received: October 22, 2014

Accepted: January 22, 2015

Online Published: April 27, 2015

doi:10.5539/emr.v4n1p5

URL: http://dx.doi.org/10.5539/emr.v4n1p5

\begin{abstract}
Professional Project Management Practice (PPMP) has become a resource tool in the $21^{\text {st }}$ century in diverse discipline, especially the construction industry where the genesis of the concept and its theory began. To this extent, Ghana has recently added an impetus to this popularity for the first time specifically mentioning and recognizing the title project managers (PMs) in the condition of contract for medium-sized works. PPMP continues to grow in the construction industry. However, there is lack of consensus and controversy among practitioners and researchers on the concept. This paper elicits the views of twenty major stakeholders in establishing a common mechanism in understanding the concept. The methodology was based on schedule interview with identified stakeholders and qualitative approach was used in the discussion. The findings of this study indicate that while theoretical knowledge exists, there is a lack of practical knowledge of the Professional Project Management among construction stakeholders. The implication of the findings is for the future development of the project management profession in Ghana and developing countries facing similar challenges as the industry advances.
\end{abstract}

Keywords: Professional Project Management Practice, stakeholders, concept, construction industry, Ghana

\section{Introduction}

Project management is now well developed and has been accepted as a domain for the exercise of professional expertise and for academic research discourse (White \& Fortune, 2002). These are seen in many emerging industries and sectors such as Information Technology (IT), management consultancy and product design and manufacturers (Cheng, 2005). The construction industry is perhaps perceived tube the largest and most established project management practice (Crawford et al., 2006). However, its practices is highly a problematic endeavour in most developing countries (Cheng et al., 2005) due to the fact that there exists within a complex multidisciplinary team-oriented environment (Crawford et al., 2006). In buttressing this, Cooke-Davies (2000) and Blackburn (2002) indicated that results continue to be disappointing for stakeholders in terms of project performance and success. Conversely, the demand for project management practices in developing countries such as Ghana continues to grow. According to Godwin (1993), an effective project management decision rank as a single most influential contributor to achieving improved performance. It should however be noted that, project management knowledge and practices varies between industries, countries and application areas (Crawford et al., 2006). However, in Ghana, it appears that practitioners and researchers are confused about what constitute project management practices and regulations. This paper therefore, was articulated with the aim to enquire the knowledge base of construction professional on the extent of the practices of professional project management in the Ghanaian Construction Industry (GCI).

\section{Project Management Practices}

Project Management (PM) as a professional practice that transcends national and industry boundaries has been in existence since the creation of mankind. The evolution of PPMP had its beginnings in construction, defence and engineering organizations (Morris, 1994). Professional Project Management gained popular attention in the area of management literature in the late 1950s (Gaddis, 1959) although its heydays is widely seen to be in the late 
1960s and early 1970s (Winch, 2000).

In addition, Project Management (PM) system promises to deliver "one-off" undertakings "on time, to budget, within scope" (Morris, 1997), through the planning and control of variables including resources, cost, productivity, schedule, risk and quality (Atkinson, 1999). Notwithstanding, the current state of project management practices in developing African countries such as Ghana remain very critical due to the advancement of technology, the increasing complexity of projects and the scarcity of human capital (Thomas \& Winter, 2006). Similarly, Ahadzie and Amoah-Mensah (2010) argues that the expansive role of the private sector in recent time in the infrastructure and supply has not increased any better, due to the fact that there is no indication that project management practice in countries in this country has received any knowledge-based improvement. Although, professional project management practices in Ghana, specifically the construction industry emerged around 1980s through projects initiated by the Social Security and National Insurance Trust (SSNIT) in response to stakeholders (i.e. clients, general public, government agencies) demand for quality of work and construction within cost and time, as stipulated by the conditions of contract (Ahadzie \& Amoah-Mensah, 2010).

The practice saw improvement and recognition after 2003 when the government officially through the condition of contract for medium-sized contract of works made specific mention of the title project manager, which in other sense has given a legal backing for the practices in public sector. Quite recently, the private sector through alliance with their development partners has also established the Ghanaian Chapter of Project Management Institute (PMI) with the aim of providing leading edge in the practices of project management.

Notwithstanding, the evidence is clear that PPMP in Ghana is faced with challenges, indeed, the cessation of the 5000 National Affordable housing project initiated in 2000, the "mother and child" unit which started in the year 2001 at Okomfo Anokye Teaching Hospital are examples of uncompleted construction projects with its period over exceeded. This is a wake-up call, for key players in the GCI to put in measures for effective practices that will improve project performance. It is therefore no doubt that the foregoing research tends to examine the theoretical base of project management practice within the GCI.

\section{Methodology}

This paper adopted an exploratory method (qualitative techniques) in its data collection. Purposive sampling technique was adopted in the administration of questionnaire, in order to provide the best perspective on the phenomenon under study. In all, a total sample size of twenty was involved, which was made up of five clients (three in the public sector and two unnamed due to ethical reasons but labelled CL2 and CL3) and consultants (two in the public sector and three unnamed due to ethical reasons but labelled as CON 2, CON 3 and CON 3). In addition, five major contractors unnamed but labelled as (CONT1, CONT 2, CONT 3, CONT 4 and CONT 5) and institutions that are involved in regulating the construction industry (see table 1). These organisations were chosen because of their experiences in the GCI and the type of project they have undertaken over the past years and recently. It is worth noting that qualitative research usually relies on small numbers with the aim of studying in-depth of a phenomenon. Drawing on Baum (2002) 12-20 data sources is good for achieving maximum variation; hence the research was in this direction. Data was collected by the use of semi-structured interviews and was then transcribed and coded using Nvivo 8 Software. Thus, the software involves the thinking, reflecting, linking elements of data and annotating of the contents of responses and documents thereby allowing factors to emerge. However, in order to increase the reliability of the answers, all interviews were recorded, subsequently transcribed material was sent back to respondents and their statements were amended according to the respondents' comments. 
Table 1. Sample for qualitative study

\begin{tabular}{|c|c|c|c|}
\hline Clients & Consultants & Contractor & Institution \\
\hline $\begin{array}{lr}\text { Social } & \text { Security } \\
\text { and Insurance } \\
\text { Trust(SSNIT) }\end{array}$ & $\begin{array}{l}\text { Building and Road } \\
\text { Research } \\
\text { Institute(BRRI) }\end{array}$ & CONT 1 & $\begin{array}{l}\text { Ghana Institution of Surveyor } \\
\text { (GhIS) }\end{array}$ \\
\hline CL 2 & CON 2 & CONT 2 & $\begin{array}{l}\text { Ghana Institution of Engineers } \\
\text { (GhIE) }\end{array}$ \\
\hline $\begin{array}{l}\text { Ministry of } \\
\text { Water, Work and } \\
\text { Housing }\end{array}$ & CON 3 & CONT 3 & $\begin{array}{l}\text { Ghana Institution of Architect } \\
\text { (GIA) }\end{array}$ \\
\hline CL 3 & CON 4 & CONT4 & $\begin{array}{l}\text { Project Management Institute, } \\
\text { Ghana Chapter (PMI) }\end{array}$ \\
\hline $\begin{array}{lr}\text { Ghana } & \text { Education } \\
\text { Trust } & \text { Fund } \\
\text { (Getfund) } & \end{array}$ & $\begin{array}{l}\text { Architectural } \\
\text { Engineering And } \\
\text { Services Limited }\end{array}$ & CONT 5 & $\begin{array}{l}\text { Association of Building and } \\
\text { Civil } \\
\text { Ghana.(ABCEG) }\end{array}$ \\
\hline
\end{tabular}

\section{Discussion and Findings}

The fundamental concept of this paper was underpinned on Godwin (1993) postulation that the fundamental concept on which project management hinged is on the basis that a single individual (the project manager) is accountable for the success of the project. In the same vein, Winch (2000) and Walker (2002) admitted to the fact that Project Management Concept is about a single individual, accountable for the success of the project including planning, execution, monitoring and control, and closing of projects. Ahadzie and Amoah-Mensah (2010), proposed that Professional Project Management Practices (PPMP), in the construction industry could be used to define a situation where an independent entity, be it an individual or a consortium, is appointed beside the design team to take responsibility for the management of design and construction phases of a project from conception to completion (Ahadzie \&Amoah-Mensah, 2010). The discussion and finding are as follows:

\subsection{Project Management (PM)}

Every organization or institution has a conceptualized definition for project management. Similarly, the term Project Management has become one of the most common term used by various stakeholders in the construction industry. Hence, most of the respondents explain Project Management as follows:

"PM is a set of management processes for creating any unique value in a project context, which is mission driven, systematic, time bound, and resource constrained" (informants'view).

However, this definition as given by the respondents records the same understanding by several authors notably Akewushola et al. (2012) and Walker (2002). In addition, five respondents were of the view that there should be three basic principles guiding the definition as commented below:

"Establishment of the requirements and objectives of the project, the formulation of a management plan to meet the objectives of the project and ensuring that the project completed successfully and that the necessary stakeholders accept all deliverables"(informants'view).

This concurs with the assertion by Koskela and Howell (2002) on the three basic action of PM. More so, definitions vary depending on the type of industry or discipline under consideration, which confirms Ahadzie et al. (2005) asserting that definition varies depending on the industry under consideration.

\subsection{Project Managers (PMs)}

The term project manager is well known and has been attributed to the success or failure of a project. Ahadzie et al. (2005) indicated that the definition for the title PMs is a subject that remains debatable amongst academic writers. However, the title commented are follows:

"Project manager is in two parts thus; project manager on the perspective of the client and that of the contractor" (informants'view).

Not with standing, Walker (2002) argues that, it is necessary to concentrate on the duties of the PMs rather than what should be the precise definition. As lamented by the respondents as follows: 
"On the perspective of the client, project manager is the leader of the construction team and liaison officer between the client and the design team thereby coordinating the works of the consultants and managing the project from inception to completion acting as a separate entity or part of the consultant group" (informants-Consultants). "Project managers are referred to as project directors or coordinators as per their roles they undertake within government institutions" (informants' client organization). "Project management on the perspective of the contractor, they act as spokesperson to the construction team and they must not be referred to as project managers but instead contract manager" (informant construction companies).

Despite this, the research is pinned on a situation of having one individual or an entity-managing project from inception to completion thereby harnessing resources to achieve the desirable of the client (Godwin, 1993; Winch, 2000).

\subsection{Educational Level of Project Managers}

The need for successful completion of a project and management skills depends on the educational level of PMs (Hatchett, 1980), it is therefore imperative to examine the educational level and training needs of PMs in developing their knowledge and skills. As indicated by respondents:

"The minimum educational level of PMs is a tertiary degree either a Bachelor or Higher National Diploma (HND) with requisite experience. In addition, fresh graduates from tertiary institutions cannot assume the position of PMs, whether his or her tertiary degree is in PM' (informants 'view).

This finding is in accordance with Enhassi et al. (2009) who indicated that novice should not manage construction site, since requisite skills, knowledge, and experience are required for effective and efficient project management practices. Moreover, professional recognition, through associations with professional bodies have become predominant among Project Management Professionals for boosting individual career development and should not be the main yardstick for job placement. On this basis, the research probes further into project manager qualification, which it remains a contentious question (Ahadzie et al., 2005) of what should be the appropriate professional background of the PMs. As recounted by respondents;

"Any professional in the built environment can be qualified to be a construction project manager" (informants' view).

This however, contradicts with the assertion of CIOB (2002) and Ogunlana et al. (2002) that PMs can be from any professional background. However, this finding is mainly in the context of respondents working experience and environment in which they operate. In addition, construction is technical in nature and requires technical knowledge and experience, which are key factors in achieving a comprehensive and effective Project Management System. PM is therefore not only about the use of Project Management tools and systems but individual technical expertise. Drawing from the above, the research advances that there should be training processes for which Construction Project Managers go through in order to qualify as project manager. This training should deal with the following requirement as lamented by respondents:

"Advance training in PM; Exposure and knowledge in managing projects; Must have worked under someone not less than five years; Ability to organise work and personnel; and Knowledge in contract administration" (informants' institution).

Furthermore, the research establishes a training process for efficient and effective training of Construction Project Manager as indicated in the Figure 1. 


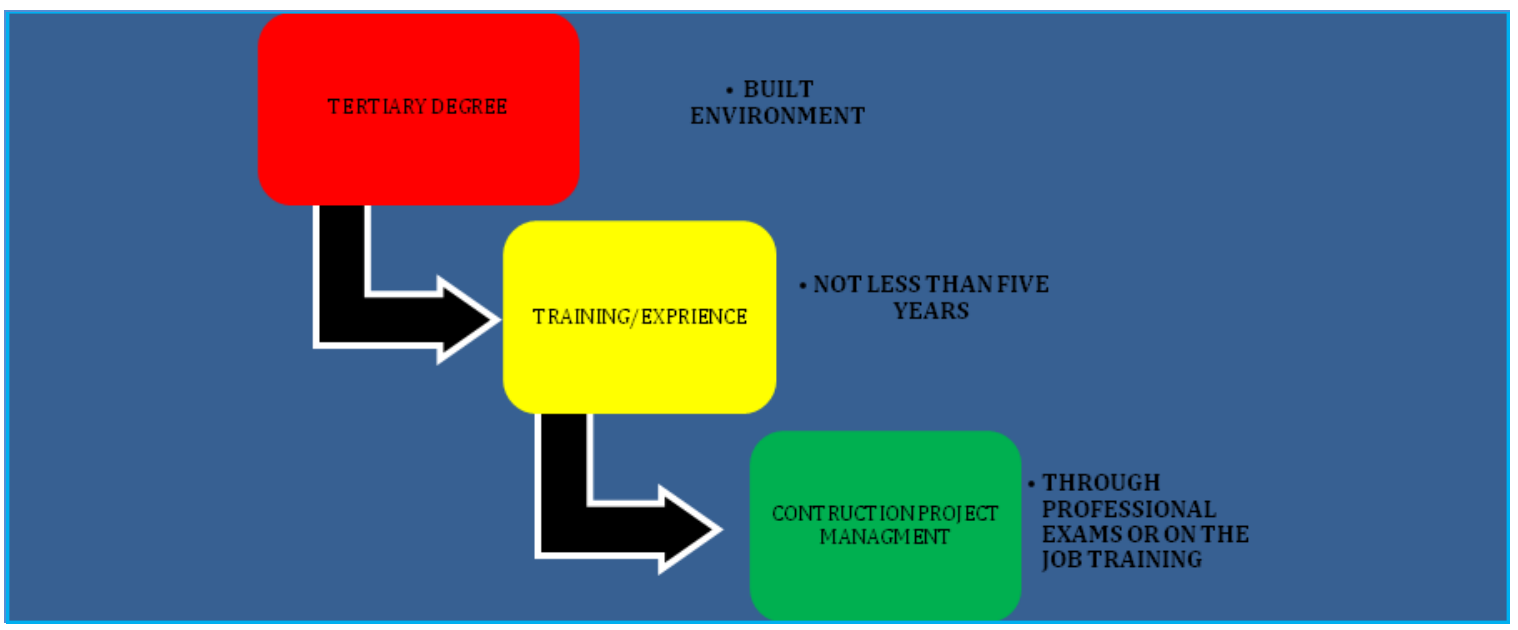

Figure 1. Training process for Construction Project Manager (CPM)

Not with standing, some of the respondents were of the view that so far as you have the right qualification in PM you can manage any project in any field, whether hospital, construction, engineering or business. They also contend that PM is about the use of project management tools and systems not necessary about experience.

\subsection{Lead Consultant versus Project Management}

The issue of Project Management and lead consultancy system continues to be one of the major concepts that researchers and practitioners lack consensus. This study revealed that the lead consultant has direct contract with the client as several individual consultants also have their own contract with client. Nevertheless, he sometimes might act as the administrative head or project coordinator and project administrator. However, the project manager is a one-stop shop system where clients deal only with the project manager having other people or consultants working under him or her with no contractual relationship with the client.

Moreover, the project manager is more of a specialty or trade training than the lead consultant who has much weakness in dealing with modern construction system such as integrated approach in stakeholders' management. In addition, it also revealed that some lead consultants assumed the position as project managers but due to lack of their understanding to modern construction techniques and the use of various PM tools has accounted for cost and time overrun; and poor managerial techniques in handling disputes arising out of the project.

Furthermore, the condition of contract for medium-sized works, of Ghana gives further indication of the need for of project management practices in GCI. Hence, according to respondents:

"They were aware of the project management system via the condition of contract for medium-sized works in the making of a specific mention of the title project manager. However, they indicated that roles given in the tender document of works is not comprehensive enough, it lacks technical expertise of a project manager and the meaning is too shallow to fit the role to be performed by the project manager. And three were not aware" (informants'view).

\subsection{Challenges Affecting Practicing of PMPP}

PMPP in the construction industry is strongly beneficial to the users however; research revealed there are various challenges confronting the construction industry in the practices Project Management in Ghana. Here the Nvivo 8 helped in identifying eighteen key constraints. It was observed that nine of these constraints were consistent with literature on Project Management (see table 2), whilst the remaining nine were inconsistent suggesting that they could be peculiar to conditions pertain to project management practices in the Ghanaian Construction Industry. 
Table 2.Variables posing challenges to PM practices in Ghana

\section{Consistent with Literature}

Inadequate knowledge of construction project management practices by government agencies /public service (Rwelamila, 2004; Gow and Morss, 1988; Kartam et al., 2000).

Construction professional's inability to acquire basic knowledge in project management (Du, 2001).

Misunderstanding among construction professionals on project management concepts (Liu 2004).

Poor definition of construction project scope (Chung-Suk and Edwards, 2001).

Lukewarm attitude towards change by construction professionals (Loo,2002)

Communication barriers among project participants (Abbasi And Al-Mharmah, 2000).

Lack of client understanding of what they want from construction professionals (Irem, 2005).

Increasing complexity of projects and the scarcity of human capital (Crawford et al., 2006).

Difficulty in accessing information on project management theory in practices (Koskela and Howell, 2002; Shenhar 1998; Turner, 1999).

\section{Inconsistent with Literature and Unique to Ghanaian Practice}

Lack of ethics and code of practice for construction project management professionals.

Inadequate legislative framework and enabling environment for project management practices.

The unwillingness of construction professionals to accept the role of project managers.

Non-availability of project management training facilities for construction professionals.

Poor understanding of procurement practices.

Wrong choice of procurement approach

Insufficient technical details and specification in contract documentation.

Limited authority for project managers in contractual documentation.

Ignorance of the benefits of project management practices over other traditional management principles.

\subsection{Strategies for Development of the PPMP}

All respondents lamented on the following as a medium for the improvement of the practices PM in GCI. Hence, they indicated that for efficient system to be in place the following strategies should be follow:

- "Setting up a regulatory body, to be responsible in managing and determining various credentials and qualifications in construction project management;

- Continuous Professional Development, (CPD) of construction professionals through regular seminars, workshop, and refresher courses;

- Awareness creation among organisations and institutions such as government agencies and professional bodies; Project management must be part of the educational curriculum from pre tertiary-to-tertiary level;

- Developing an attitude at the corporate level by treating any assignment as project with assigning roles to all members in the organisation;

- Policy makers recognising the benefits of project management and incorporating procurement laws and enforced to the letter; and

- Stakeholders' engagement and round table discussion should be encouraged among project participant e.g. pre-construction conference" (informants'view)

\section{Conclusion}

Professional Project Management practices in developing African countries like Ghana continues to grow. However, stakeholders are confused of what really constitute project management practices in the Ghanaian construction industry. This paper enquired the knowledge of professionals, based on their practices in Ghanaian 
construction industry. Hence, the empirical data established that practical reference of the emerging recognition of project management as a discipline and profession is gaining grounds in Ghana. The evidence gathered suggest that, while in theory the definition and popularity of Project Management is not in doubt, its practical relevance is far from being clear. Given that, the title project manager is now contractually required on many donor funded, public and some private sector procurement in Ghana. Therefore, there is need to rigorously pursue the advancement and deployment of professional project management practice as a core managerial practice in the Ghanaian Construction Industry.

\section{Reference}

Ahadzie, D. K., Proverbs, D. G., \& Olomolaiye, P. (2004). Meeting Housing Delivery Target in Developing Countries: The Project Managers Contribution in Ghana. In The Construction Industry in Developing Countries, International Conference on Globalization and Construction, Asian Institution of Technology (AIT) (Vol. 17-19, pp. 620-630). Bangkok, Thailand.

Ahadzie, D. K., \& Amoah-Mensah, K. (2010). Management Practices in the Construction. Ghanaian House Building Industry. Journal of Science and Technology, 30(2), 62-75.

Akewushola, R., Olawale, I., \& Hammed, O. G. (2012). Effect of Project Management on Project Success. Australian Journal of Business and Management Research, 2(3), 1-11. http://dx.doi.org/10.1016/S0263-7863(98)00069-6

Atkinson, R. (1999). Project Management: Cost, Time and Quality, Two Best Guesses and a Phenomenon, it's Time to Accept other Success Criteria. International Journal of Project Management, 17(6), 337-342.

Baum, F. (2000). The New Public Health. Oxford: Oxford University Press.

Chung-Suk, C., \& Edward, G. (2001). Building Project Scope Definition Using Project Definition Rating Index. $\begin{array}{llll}\text { Journal of Architectural } & \text { Engineering, } & \text { 7(4), }\end{array}$ http://dx.doi.org/10.1061/(ASCE)1076-0431(2001)7:4(115)

CIOB. (2002). Code of Practice for Project for Construction and Development. United Kingdom: Blackwell Publishing.

Cooke-Davies, T. J. (2000). Towards Improved Project Management Practice. Leeds Metropolitan University.

Crawford, L. H, Morris P., Thomas J., \& Winter M. (2006). Practitioner Development: From Trained Technicians to Reflective Practitioners. International Journal of Project Management, 24, 722-733. http://dx.doi.org/10.1016/j.ijproman.2006.09.010

Crawford, L. H. (2001). Project Management Standards: The Value of Standards (DBA Thesis). Henley-on-Thames: Henley Management College/Brunel University.

Du, Y. M. (2001). Developing China's Construction Supervision System. Anhu Construction Supervision, 8(1), $2-5$.

Enshassi, A, Al-Najjar, J., \& Kumaraswamy, M. (2009). Delays and Cost Overruns in the Construction Project in the Gaza Strip. Journal of Financial Management of Property and Construction, 14, 126-151. http://dx.doi.org/10.1108/13664380910977592

Field, B., \& Ofori, G. (1988). Construction and Economic Development, a Case Study. Third World Planning Review, 10(1), 41-50.

Ghana Procurement Authority. (2003). The Procurement Act 663. Accra, Ghana.

Goodwin RSC. (1993). Skills Required of Effective Project Managers. Journal of Management in Engineering, 9 , 217-226. http://dx.doi.org/10.1061/(ASCE)9742-597X(1993)9:3(217)

Gow, D., \& Morss E. (1988). The Notorious Nine: Critical problems in Project Implementation. World Development, 16(12), 1399-1418. http://dx.doi.org/10.1016/0305-750X(88)90216-1

Guiwenm, L., Qiping, S., Heng, L., \& Liyin, S., (2004). Factors Constraining the Development of Professional Project Management in China's Construction Industry. International Journal of Project Management, 22, 203-211. http://dx.doi.org/10.1016/S0263-7863(03)00068-1

Hatchett, M. (1980). Possibilities for Future Development in the Prestige of Site Management. In The Practice of Site Management (pp. 10-12). Ascot, U.K.

Irem, D. M., Talat, B., \& Semiha, K. (2005). Strategic use of Quality Function Deployment (QFD) in the

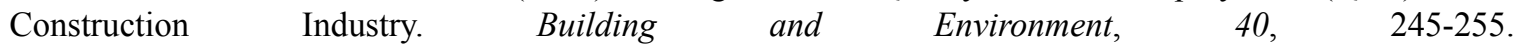


http://dx.doi.org/10.1016/j.buildenv.2004.07.001

Kartam, N., Al-Daihani, T. G., \& Al-Bahar, J. F. (2000). Professional Project Management Practices in Kuwait: Issues, Difficulties and Recommendations. International Journal of Project Management, 18(2), 105-109. http://dx.doi.org/10.1016/S0263-7863(99)00017-4

Kloppenborg, T. J., \& Opfer, W. A. (2000). Forty Years of Project Management Research: Trends, Interpretations, and Predictions. Proceedings of PM Research Conference Pairs Project Management Institute.

Koskela, L., \& Howell, G. (2002). The Underlying Theory of Project Management is Obsolete. Proceedings of the PMI Research Conference (pp. 293-302).

Lynn, C. (1998). Standards for Global Profession Project Management. Proceedings of the 29th Annual Project Management Institute Seminars \& Symposium Long Beach, California, USA: Papers Presented October 9 to 15 .

Morris, P. W. (1994). The Management of Projects. London: Thomas Telford. http://dx.doi.org/10.1680/mop.16934

O'Connor, M. M. (1992). Quality Project in the 1990s Review of Past Projects and Future Trends. International Journal of Project Management, 10(2), 107-114. http://dx.doi.org/10.1016/0263-7863(92)90063-F

Odusami, K. T., \& Iyagba, R. R. (2003). The Relationship between Project Leadership, Team Composition \& Construction Project Performance in Nigeria. International Journal Project Management, 21, 519-527. http://dx.doi.org/10.1016/S0263-7863(02)00059-5

Ogunlana, S., Siddiqui, Z., Yisa, S., \& Olomolaiye, P. (2002). Factors and Procedures used in Matching Project Managers to Construction Projects in Bangkok. International Journal of Project Management, 20, 385-400. http://dx.doi.org/10.1016/S0263-7863(01)00017-5

Rubinstein, R. (1994). Proposal Writing (pp. 67-81). London.

Shenhar, A. J. (1998). From Theory to Practice: Toward a Typology of Project Management Styles. Transactions on Engineering Management, 45(1), 33-48. http://dx.doi.org/10.1109/17.658659

Turner, J. R. (1999). Project Management: A Profession Based on Knowledge or Faith? International Journal of Project Management, 17(6), 329-330.

Walker, A. (2002). Project Management in Construction (4th ed.). Oxford: Blackwell Science Limited.

Winch, G. M. (2000). Managing Construction Projects: Information Processing Approach. Oxford: Blackwell.

\section{Copyrights}

Copyright for this article is retained by the author(s), with first publication rights granted to the journal.

This is an open-access article distributed under the terms and conditions of the Creative Commons Attribution license (http://creativecommons.org/licenses/by/3.0/). 